\title{
Differential expression and regulation of prostaglandin $E$ synthases in the mouse ovary during sexual maturation and luteal development
}

\author{
Tong Sun, Wen-Bo Deng, Hong-Lu Diao, Hua Ni, Yu-Yan Bai, \\ Xing-Hong Ma, Li-Bin Xu and Zeng-Ming Yang
}

College of Life Sciences, Northeast Agricultural University, Harbin 150030, China

(Requests for offprints should be addressed to Z-M Yang; Email: zmyang@neau.edu.cn)

\begin{abstract}
Prostaglandin (PGE) 2 is the most common prostanoid and plays an important role in female reproduction. The aim of this study was to examine the expression and regulation of microsomal (m) PGE synthase (PGES)-1 and cytosolic (c) PGES in the mouse ovary during sexual maturation, gonadotropin treatment and luteal development by in situ hybridization and immunohistochemistry. Both mPGES-1 mRNA signals and immunostaining were localized in the granulosa cells, but not in the thecal cells and oocytes. cPGES mRNA signals were localized in both granulosa cells and oocytes, whereas cPGES immunostaining was exclusively localized in the oocytes. In our superovulated model of immature mice, there was a basal level of mPGES-1 mRNA signals in the granulosa cells at $48 \mathrm{~h}$ after equine chorionic gonadotropin (eCG) treatment. mPGES-1 mRNA level was induced by human chorionic gonadotropin (hCG) treatment for $0.5 \mathrm{~h}$,
\end{abstract}

whereas mPGES-1 immunostaining was slightly induced at $0.5 \mathrm{~h}$ after hCG treatment and reached a maximal level at $3 \mathrm{~h}$ after hCG treatment. eCG treatment had no obvious effects on either cPGES mRNA signals or immunostaining. A strong level of cPGES immunostaining was present in both unstimulated and eCGtreated groups. Both mPGES-1 mRNA signals and immunostaining were highly detected in the corpus luteum 2 days post-hCG injection and declined from days 3 to 7 post-hCG injection. cPGES immunostaining was at a basal level or not detectable from days 1 to 7 after hCG injection and was highly expressed in the corpus luteum from days 9 to 15 post-hCG injection. PGE2 biosynthesized through the mPGES-1 pathway may be important for follicular development, ovulation and luteal formation. Journal of Endocrinology (2006) 189, 89-101

\section{Introduction}

Prostaglandins (PGs) consist of a diverse family of autacoids derived from cyclo-oxygenase (COX) metabolism of arachidonic acid to $\mathrm{PGG} 2 / \mathrm{PGH} 2$, leading to the production of five major bioactive prostaglandin metabolites: PGE2, PGF2 $\alpha$, PGD2, PGI2 and thromboxane A2 (TXA2) (Smith 1992). PGE2 is the most common prostanoid with a broad range of biological activities in diverse tissues through its binding to specific receptors on plasma membranes and has been involved in various pathologies (Murakami et al. 2002). PGE receptors are pharmacologically subdivided into four subtypes: EP1, EP2, EP3 and EP4 (Coleman et al. 1994, Sugimoto et al. 2000).

PGE synthase (PGES) is a terminal prostanoid synthase and can catalyze the isomerization of the COX product PGH2 to PGE2. There are three isoforms of PGES, microsomal PGES-1 (mPGES-1), cytosolic PGES (cPGES) and mPGES-2 (Murakami et al. 2002, Tanikawa et al. 2002). cPGES is constitutively expressed in a wide variety of cells and tissues, and predominantly linked with
COX-1 to promote the immediate response, during which relatively high concentrations of arachidonic acid are released in a short period (Tanioka et al. 2000). mPGES-1, a membrane-associated and inducible perinuclear enzyme with glutathione-dependent activity, is expressed in a variety of tissues including prostate, testes and small intestine (Jakobsson et al. 1999). mPGES-1 is preferentially coupled with the inducible COX-2 to promote delayed PGE2 generation and, if COX-2 already exists in cells, also regulates immediate PGE2 generation (Murakami et al. 2000). Unlike mPGES-1, mPGES-2 does not require glutathione for catalytic activity and is activated in the presence of a broad range of reducing agents (Tanikawa et al. 2002).

Aspirin-like drugs that inhibit COX have been reported to inhibit spontaneous and gonadotropin-primed ovulation in many species (Murdoch et al. 1993). However, PGE2, a dominant prostanoid in the ovary, can reverse the inhibitory effect of aspirin-like drugs (Wallach et al. 1978). Additionally, mPGES-1 is preferentially coupled with the inducible COX-2 to promote delayed PGE2 generation 
(Murakami et al. 2000). COX-2(-/ - ) female mice are infertile because of abnormalities in ovulation, fertilization, implantation and decidualization (Dinchuk et al. 1995, Lim et al. 1997). The defect in ovulation in COX-2 mutants was attributed to both an abnormal cumulus oophorum expansion and subsequent stigmata formation (Davis et al. 1999). Furthermore, EP2 is involved in cumulus expansion in the oviduct in vivo and the absence of EP2 receptor results in partially defective ovulation and fertilization processes (Challis 1997, Hizaki et al. 1999, Sugimoto et al. 2000).

Although PGE2 is essential for female reproduction, PGES expression and regulation in the mouse during female reproduction had not been studied except for the expression and regulation of MPGES-1 and cPGES in the mouse uterus during early pregnancy ( $\mathrm{Ni}$ et al. 2002, 2003). The aim of this study was to examine the expression and regulation of $\mathrm{mPGES}-1$ and cPGES in the mouse ovary during sexual maturation, gonadotropin treatment and luteal development.

\section{Materials and Methods}

\section{Sexual maturation}

Immature female mice (Kunming White outbred strain, 21 days old) were caged in a controlled environment with a $14 \mathrm{~h}$ light: $10 \mathrm{~h}$ darkness cycle. All animal procedures were approved by the Institutional Animal Care and Use Committee of Northeast Agricultural University. Mouse ovaries were collected on days 1, 5, 10, 15, 20, 25 and 30 after birth. There were at least three mice per group.

\section{Gonadotropin treatment}

The mice (21 days old) were superovulated with an i.p. injection of $5 \mathrm{IU}$ equine chorionic gonadotropin (eCG). Ovaries were collected from the treated mice at $0.5,1$, $3,6,12,24,36$ and $48 \mathrm{~h}$ after eCG injection. Ovaries were collected directly from 21-day-old immature mice as controls.

In addition, 21-day-old mice were superovulated with an i.p. injection of 5 IU eCG followed by administration of 5 IU human chorionic gonadotropin (hCG) $48 \mathrm{~h}$ later. Ovaries were collected from these treated mice at $0 \cdot 5$, $1,3,5,7,9,11$ and $13 \mathrm{~h}$ post-hCG injection and on days $1,2,3,4,5,7,9,11,13$ and 15 post-hCG injection respectively. Day 0 was designated as the day when hCG was injected. There were at least three mice per group.

\section{Immunohistochemistry}

Mouse ovaries were immediately fixed in Bouin's solution, dehydrated and embedded in paraffin. Sections
(7 $\mu \mathrm{m})$ were cut, deparaffinized and rehydrated. Nonspecific binding was blocked in 10\% normal horse serum in PBS for $1 \mathrm{~h}$. The sections were incubated with rabbit anti-human mPGES-1 or rabbit anti-human cPGES (Cayman Chemical, Ann Arbor, MI, USA) in 10\% horse serum overnight at $4{ }^{\circ} \mathrm{C}$. After washing in PBS three times for $5 \mathrm{~min}$ each, the sections were incubated with biotinylated goat anti-rabbit IgG followed by an avidinalkaline phosphatase complex and Vector Red according to the manufacturer's protocol (Vectastain ABC-AP kit; Vector Laboratories, Burlingame, CA, USA). Vector Red was visualized as a red color. Endogenous alkaline phosphatase activity was inhibited by supplementing $1 \mathrm{mM}$ levamisole (Sigma) into Vector Red substrate solution. In some sections, rabbit anti-human mPGES-1 or rabbit anti-human cPGES was replaced with normal rabbit $\operatorname{IgG}$ as a negative control. The sections were counterstained with hematoxylin and mounted. The degree of staining was assessed subjectively by blinded examination of the slides by two investigators.

\section{In situ hybridization}

In order to prepare mouse mPGES-1 probe for in situ hybridization, the total RNAs from mouse uteri were reverse transcribed and amplified with forward primer 5'-CGGAATTCACACTGCTGGTCATCAAG and reverse primer 5'-CGGGATCCTTCAGCTGCTG GTCACAG (Genbank accession number AB041997). In these primers, protection bases (CG) and EcoRI site were added at the $5^{\prime}$ end of forward primer, and protection bases (CG) and BamH1 site at the $5^{\prime}$ end of reverse primer. The PCR fragment (427 bp, 108-518 bp) for mPGES-1 was recovered from the agarose gel and cloned into pGEM-3Zf $(+)$ plasmid through EcoRI and BamH1 sites respectively. The cloned mPGES-1 fragment was further verified by sequencing. These plasmids were linearized with appropriate enzymes for labeling.

In order to prepare mouse cPGES probe for in situ hybridization, total RNAs from the mouse uterus on day 7 of pregnancy were reverse transcribed and amplified with forward primer $5^{\prime}$-ATGCAGCCTGCTTCTGCA and reverse primer $5^{\prime}$-TTACTCCAGATCTGGCAT designed according to human p23 (233-715 bp; Genbank Accession number L24804) (Tanioka et al. 2000). The amplification of cPGES cDNA was carried out for 35 cycles at $94{ }^{\circ} \mathrm{C}$ for $30 \mathrm{~s}, 60^{\circ} \mathrm{C}$ for $30 \mathrm{~s}$ and $72{ }^{\circ} \mathrm{C}$ for $45 \mathrm{~s}$. The amplified fragment ( $483 \mathrm{bp}$ ) of cPGES was recovered from the agarose gel and cloned into pGEM-T plasmid (pGEM-T Vector System 1; Promega). The orientation of cPGES fragment in pGEM-T plasmid was determined by a combination of the primers for T7, SP6 and 23 . The cloned cPGES fragment was further verified by sequencing and compared with the corresponding region of the human p23 sequence (233-715 bp; Genbank 
Table 1 mPGES-1 and cPGES expression during sexual maturation

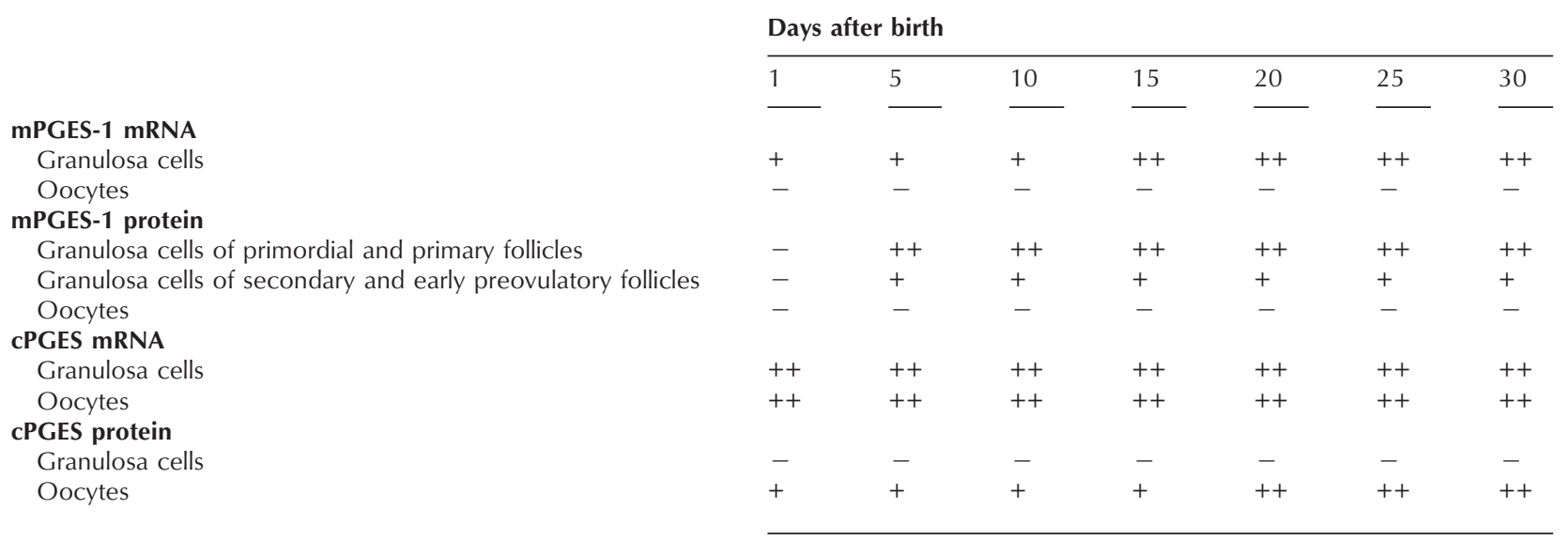

Accession number L24804). There was 95\% homology between mouse cPGES and human p23. These plasmids were linearized with appropriate enzymes for labeling. Digoxigenin (DIG)-labeled antisense or sense cRNA probes were transcribed in vitro using a DIG RNA labeling kit (Roche Diagnostics).

Mouse ovaries were snap frozen in liquid nitrogen. Frozen sections $(10 \mu \mathrm{m})$ were mounted on 3-aminopropyltriethoxy-silane (Sigma)-coated slides and fixed in $4 \%$ paraformaldehyde solution in PBS. The sections were washed in PBS twice, treated in 1\% Triton-100 for $20 \mathrm{~min}$ and washed again in PBS three times. Following the prehybridization in the solution of $50 \%$ formamide and $5 \times \operatorname{SSC}(1 \times$ SSC is $0.15 \mathrm{M}$ sodium chloride and $0.015 \mathrm{M}$ sodium citrate) at room temperature for $15 \mathrm{~min}$, the sections were hybridized in the hybridization buffer $(5 \times$ SSC, $50 \%$ formamide, $0.02 \%$ BSA, $250 \mu \mathrm{g} / \mathrm{ml}$ yeast tRNA, $10 \%$ dextran sulfate and $1 \mu \mathrm{g} / \mathrm{ml}$ denatured DIG-labeled antisense or sense RNA probe for mouse mPGES-1 or cPGES) at $55{ }^{\circ} \mathrm{C}$ for $16 \mathrm{~h}$. After hybridization, the sections were washed in 50\% formamide/ $5 \times \mathrm{SSC}$ at $55^{\circ} \mathrm{C}$ for $15 \mathrm{~min}, 50 \%$ formamide $/ 2 \times \mathrm{SSC}$ at $55{ }^{\circ} \mathrm{C}$ for $30 \mathrm{~min}, 50 \%$ formamide $/ 0.2 \times \mathrm{SSC}$ at $55^{\circ} \mathrm{C}$ twice for 30 min each and $0 \cdot 2 \times \mathrm{SSC}$ at room temperature for $5 \mathrm{~min}$. After non-specific binding was blocked in 1\% blocking mix (Roche Diagnostics $\mathrm{GmbH}$ ) for $1 \mathrm{~h}$, the sections were incubated in sheep anti-DIG antibody conjugated with alkaline phosphatase (1:5000; Roche Diagnostics $\mathrm{GmbH}$ ) in $1 \%$ block mix overnight at $4{ }^{\circ} \mathrm{C}$. The signal was visualized with $0.4 \mathrm{mM}$ 5-bromo-4chloro-3-indolyl phosphate and $0.4 \mathrm{mM}$ nitroblue tetrazolium in the buffer containing $100 \mathrm{mM}$ Tris- $\mathrm{HCl}$, $\mathrm{pH} 9 \cdot 5,100 \mathrm{mM} \mathrm{NaCl}$ and $50 \mathrm{mM} \mathrm{MgCl}_{2}$. Endogenous alkaline phosphatase activity was inhibited with $2 \mathrm{mM}$ levamisole (Sigma). All of the sections were counterstained with $1 \%$ methyl green in $0.12 \mathrm{M}$ glacial acetic acid and $0.08 \mathrm{M}$ sodium acetate for $30 \mathrm{~min}$.

\section{Results}

mPGES-1 expression during sexual maturation

The levels of mPGES-1 mRNA expression during sexual maturation are summarized in Table 1. There was a low level of mPGES-1 mRNA signals in the primordial follicles on day 1 (data not shown) and in the primary follicles on day 5 after birth (Fig. 1A). mPGES-1 mRNA signals were also at a low level in the secondary follicles on day 10 after birth (Fig. 1B). mPGES-1 mRNA signals became stronger in the secondary and early antral follicles from days 15 to 20 (Fig. 1C, data not shown for day 15). A high level of mPGES-1 signals was seen in the secondary follicles on days 25 and 30 after birth (Fig. 1D, data not shown for day 30). From days 1 to 30, mPGES-1 mRNA was mainly localized in the granulosa cells of the follicles, but not in oocytes (Fig. 1A-D).

The levels of mPGES-1 immunostaining during sexual maturation are summarized in Table 1 . There was no detectable mPGES-1 immunostaining in the primordial follicles on day 1 after birth (data not shown). There was a high level of mPGES-1 immunostaining in the primordial and primary follicles from days 5 to 30 (Fig. 1E-H). In the secondary and early preovulatory follicles from days 10 to 30, mPGES-1 immunostaining maintained an intermediate level in the granulosa cells (Fig. 1F-H). There was no detectable mPGES-1 immunostaining in the oocytes and stromal cells from days 1 to 30 after birth (Fig. 1E-H).

\section{cPGES expression during sexual maturation}

The levels of cPGES mRNA expression during sexual maturation are summarized in Table 1. A high level of cPGES mRNA signals was seen in the primordial, primary, secondary and preovulatory follicles from days 1 to 30 after birth. cPGES mRNA signals were localized in 


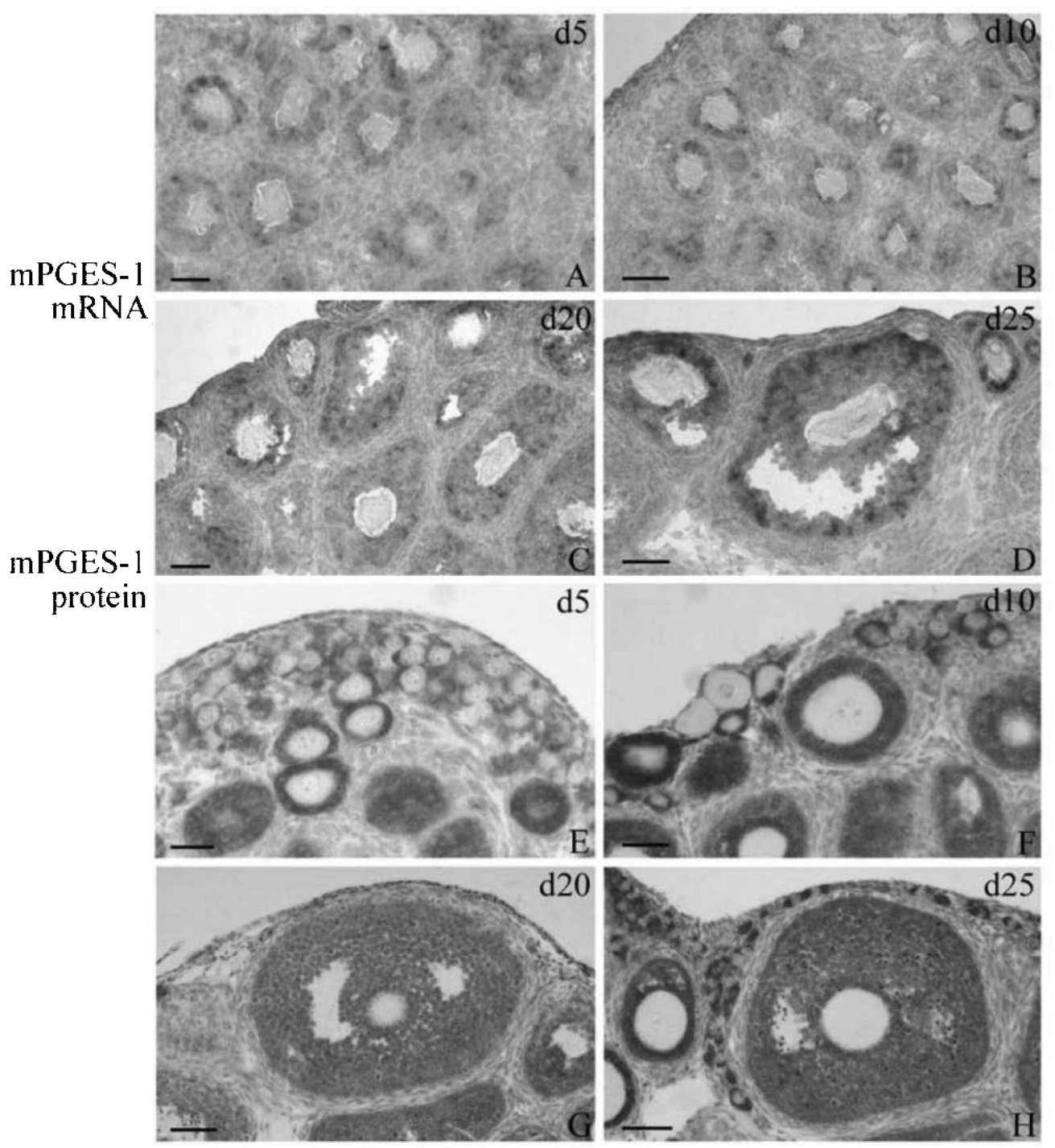

Figure 1 mPGES-1 expression in the mouse ovary during sexual maturation. In situ hybridization of mPGES-1 mRNA signals is shown in the mouse ovary on days 5 (A), 10 (B), 20 (C) and 25 (D) after birth. mPGES-1 immunostaining is shown in the mouse ovary on days $5(\mathrm{E}), 10(\mathrm{~F}), 20(\mathrm{G})$ and $25(\mathrm{H})$. The letters in the upper right corners indicate the day after birth. Bars: $45 \mu \mathrm{m}$.

both granulosa cells and oocytes. cPGES expression remained at a relatively stable level from days 1 to 30 after birth (Fig. 2A-F).

The levels of cPGES immunostaining during sexual maturation are summarized in Table 1. A basal level of cPGES immunostaining was seen in a few of the oocytes in the primordial follicles on day 1 after birth (Fig. 2G). On day 5, cPGES immunostaining was at a low level in the oocytes of primary follicles (Fig. 2H). From days 10 to 30, cPGES immunostaining was mainly detected in some of the oocytes in secondary and preovulatory follicles (Fig. 2I-L). Furthermore, cPGES immunostaining was highly detected in some of the oocytes in secondary follicles on day 20 after birth (Fig. 2K). From days 5 to 30, cPGES immunostaining was localized in the cytoplasm, but not in the nucleus of the oocytes (Fig. 2H-L). Interestingly, cPGES immunostaining was not detected in all of the oocytes even at the same stage of follicular development on the same day. Additionally, cPGES immunostaining was not detected in the granulosa cells and stromal cells in mouse ovary of all stages (Fig. 2G-L).

mPGES-1 expression after gonadotropin treatment

The levels of mPGES-1 mRNA expression after gonadotropin treatment are summarized in Tables 2 and 3. A low 


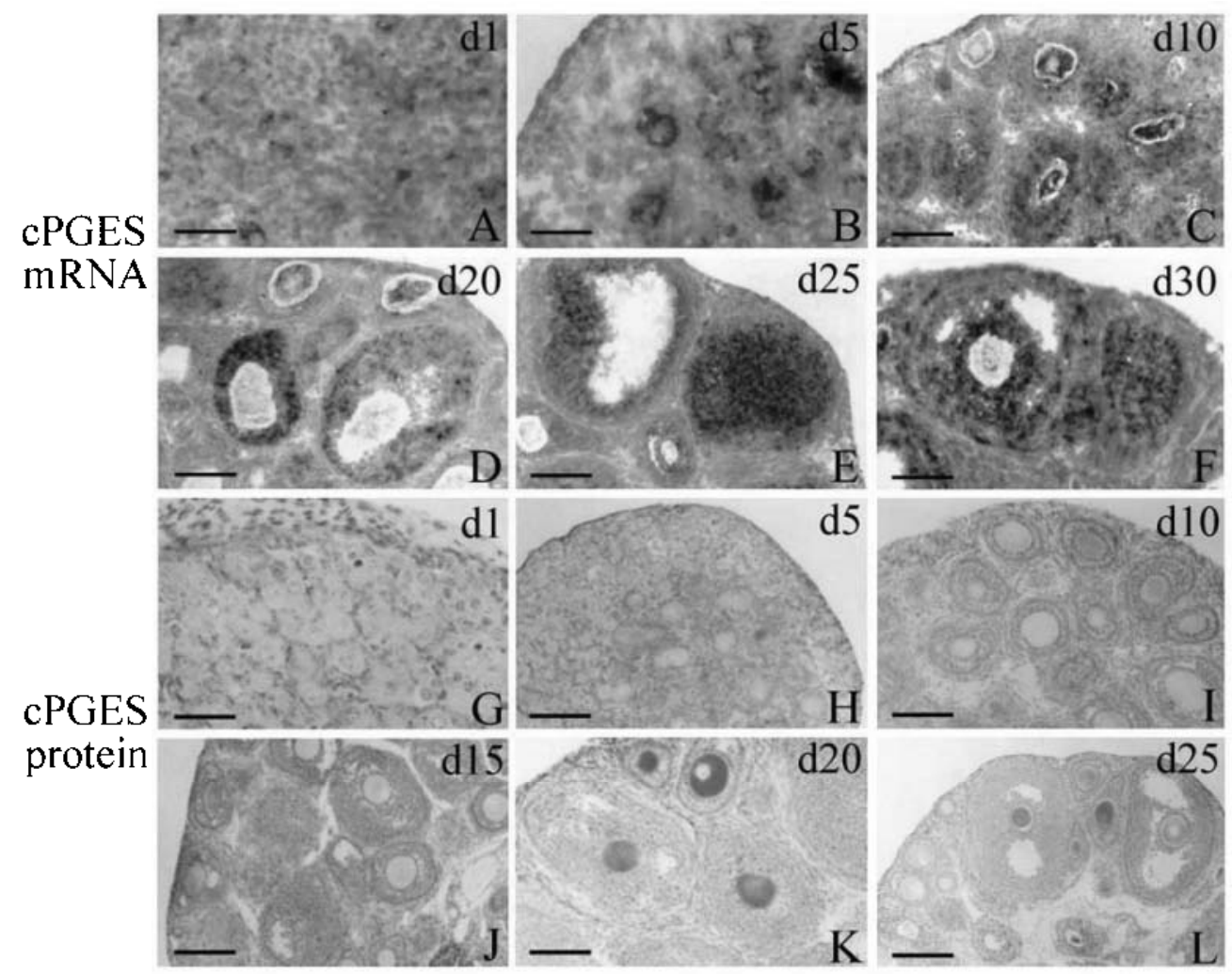

Figure 2 CPGES expression in the mouse ovary during sexual maturation. In situ hybridization of cPGES mRNA is shown on days 1 (A), 5 (B), 10 (C), 20 (D), 25 (E) and 30 (F) after birth. cPGES immunostaining is shown on days $1(\mathrm{G}), 5(\mathrm{H}), 10(\mathrm{I}), 15(\mathrm{~J}), 20(\mathrm{~K})$ and $25(\mathrm{~L})$. The letters in the upper right corners indicate the day after birth. Bars: $60 \mu \mathrm{m}$.

level of mPGES-1 mRNA signals was shown in the granulosa cells in the secondary and antral follicles in the untreated group (Fig. 3A). After treatment with eCG for $1 \mathrm{~h}$, mPGES-1 mRNA expression decreased slightly (Fig. 3B). However, a strong level of mPGES-1 mRNA signals was detected in the granulosa cells $3 \mathrm{~h}$ after
eCG treatment (Fig. 3C). When mPGES-1 sense probe was used to replace mPGES-1 antisense probe, there were no detectable signals in the ovary $3 \mathrm{~h}$ after eCG treatment (Fig. 3D). Then mPGES-1 mRNA expression dropped to a low level at 6,12 and $24 \mathrm{~h}$ after eCG stimulation (Fig. 3E and F, data not shown for $12 \mathrm{~h}$ ). There was no

Table 2 Level of mPGES-1 and cPGES after treatment with eCG

\begin{tabular}{|c|c|c|c|c|c|c|c|c|c|}
\hline & \multicolumn{9}{|c|}{ Hours after eCG treatment } \\
\hline & 0 & $0 \cdot 5$ & 1 & 3 & 6 & 12 & 24 & 36 & 48 \\
\hline \multicolumn{10}{|l|}{ mPGES-1 mRNA } \\
\hline Granulosa cells & + & + & $+/-$ & +++ & + & + & + & - & - \\
\hline Oocytes & - & - & - & - & - & - & - & - & - \\
\hline \multicolumn{10}{|l|}{ mPGES-1 protein } \\
\hline Granulosa cells & ++ & ++ & +++ & +++ & $+/-$ & $+/-$ & $+/-$ & $+/-$ & $+/-$ \\
\hline Oocytes & - & - & - & - & - & - & - & - & - \\
\hline \multicolumn{10}{|l|}{ cPGES mRNA } \\
\hline Granulosa cells & + & + & + & + & + & + & + & + & $+/-$ \\
\hline Oocytes & + & + & + & + & + & + & + & + & $+/-$ \\
\hline \multicolumn{10}{|l|}{ cPGES protein } \\
\hline Granulosa cells & - & - & - & - & - & - & - & - & - \\
\hline Oocytes & ++ & ++ & ++ & ++ & ++ & ++ & ++ & ++ & ++ \\
\hline
\end{tabular}


Table 3 Level of mPGES-1 and cPGES after treatment with hCG

\begin{tabular}{|c|c|c|c|c|c|c|c|c|}
\hline & \multicolumn{8}{|c|}{ Hours after hCG treatments } \\
\hline & $0 \cdot 5$ & 1 & 3 & 5 & 7 & 9 & 11 & 13 \\
\hline \multicolumn{9}{|l|}{ mPGES-1 mRNA } \\
\hline Granulosa cells & + & + & ++ & ++ & + & + & + & + \\
\hline Oocytes & - & - & - & - & - & - & - & - \\
\hline \multicolumn{9}{|l|}{ mPGES-1 protein } \\
\hline Granulosa cells & $+/-$ & $+/-$ & ++ & + & + & + & + & + \\
\hline Oocytes & - & - & - & - & - & - & - & - \\
\hline \multicolumn{9}{|l|}{ cPGES mRNA } \\
\hline Granulosa cells & $+/-$ & $+/-$ & $+/-$ & $+/-$ & $+/-$ & $+/-$ & $+/-$ & $+/-$ \\
\hline Oocytes & $+/-$ & $+/-$ & $+/-$ & $+/-$ & $+/-$ & $+/-$ & $+/-$ & $+/-$ \\
\hline \multicolumn{9}{|l|}{ cPGES protein } \\
\hline Granulosa cells & - & - & - & - & - & - & - & - \\
\hline Oocytes & ++ & ++ & ++ & ++ & ++ & ++ & ++ & ++ \\
\hline
\end{tabular}

detectable signal at $48 \mathrm{~h}$ after eCG treatment (data not shown). After the mice were further treated with hCG for $0.5 \mathrm{~h}$, there was a slight increase of mPGES-1 mRNA expression in the granulosa cells in the large follicles (Fig. 3G). At 3 and $5 \mathrm{~h}$ after hCG treatment, mPGES-1 mRNA signals were highly seen in the small secondary follicles and weakly seen in the oophrus cumulus cells, but not detected in the mural granulosa cells (Fig. 3H, data not shown for $5 \mathrm{~h}$ ). At 7,9 and $11 \mathrm{~h}$ after hCG treatment, mPGES-1 expression was detected only in the small secondary follicles, but not in preovulatory and ovulatory follicles (Fig. 3I, data not shown for 7 and 9 h).

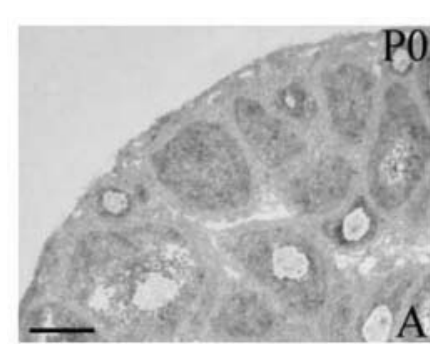

\section{mPGES- 1 mRNA}
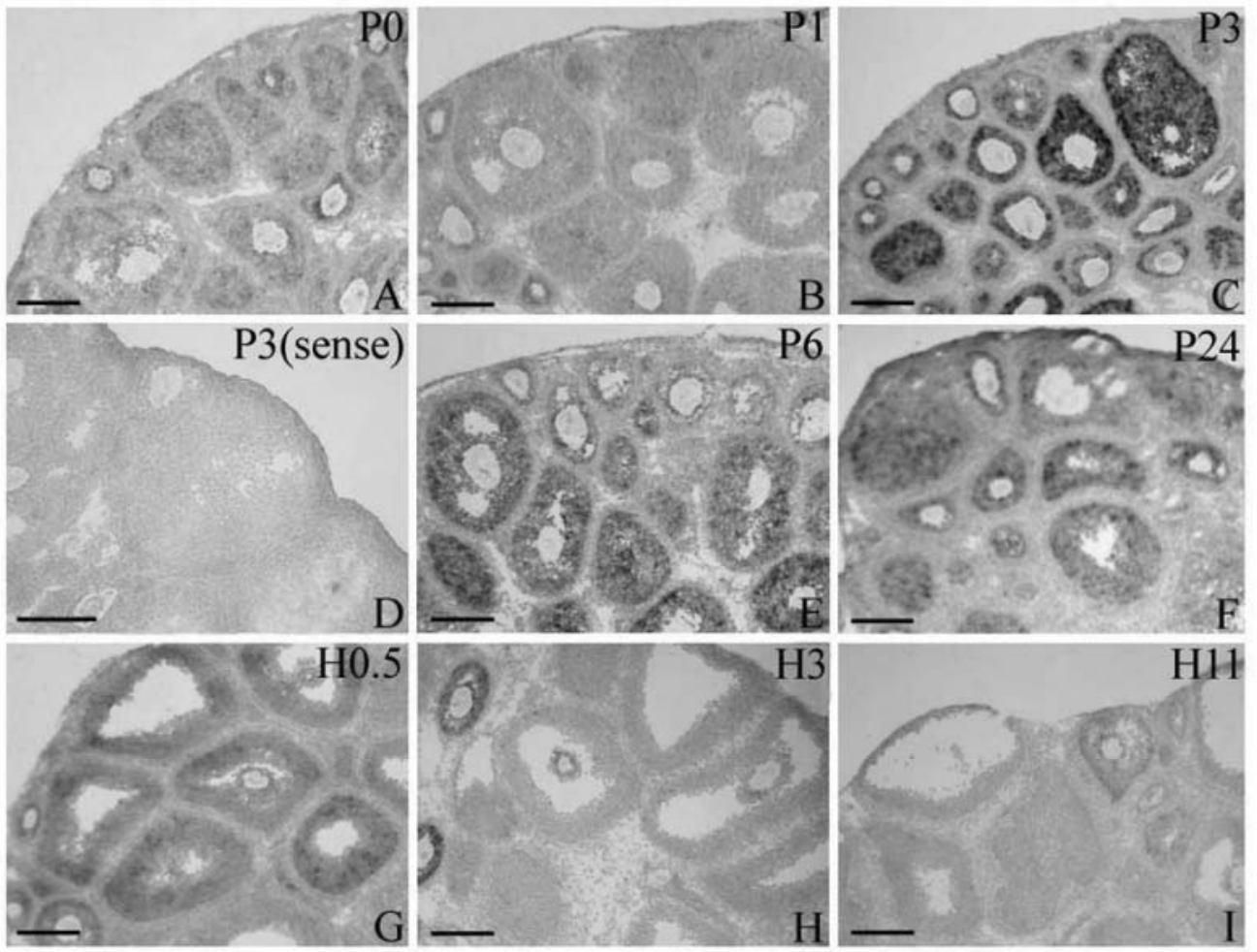

Figure 3 In situ hybridization of mPGES-1 mRNA signals in the immature mouse ovary after treatment with eCG for $1(B), 3(C), 3(D$, sense), $6(\mathrm{E})$ and $24 \mathrm{~h}(\mathrm{~F})$, followed by the treatment with hCG for $0.5(\mathrm{G}), 3(\mathrm{H})$ and $11 \mathrm{~h}(\mathrm{I})$. Untreated immature mice were used as controls (A). The letters in the upper right corners indicate the time $(\mathrm{h})$ after eCG $(\mathrm{P})$ or both eCG and hCG $(\mathrm{H})$ treatment. Bars: $60 \mu \mathrm{m}$. 


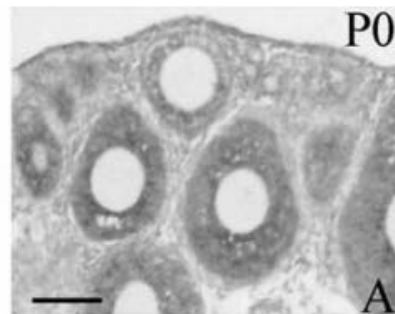

\section{mPGES-1 protein}
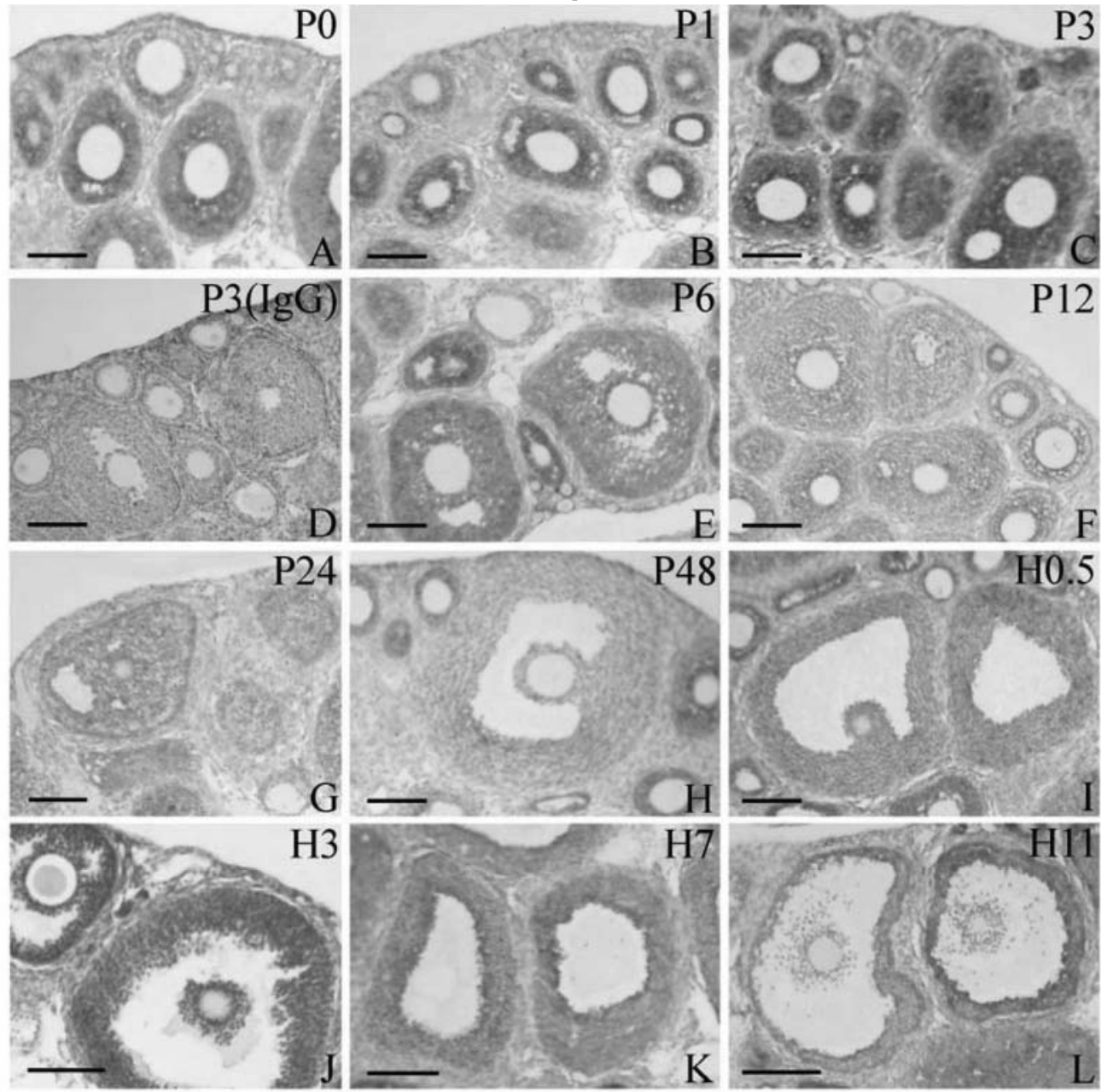

Figure 4 mPGES-1 immunostaining in the immature mouse ovary after treatment with eCG for 1 (B), 3 (C), 3 (D, rabbit $\lg G), 6(\mathrm{E}), 12(\mathrm{~F}), 24(\mathrm{G})$ and $48 \mathrm{~h}(\mathrm{H}) \mathrm{h}$, followed by the treatment with hCG for $0.5(\mathrm{I}), 3(\mathrm{~J})$, $7(\mathrm{~K})$ and $11 \mathrm{~h}(\mathrm{~L})$. Untreated immature mice were used as controls $(\mathrm{A})$. The letters in the upper right corners indicate the time $(\mathrm{h})$ after eCG $(\mathrm{P})$ or both eCG and hCG $(\mathrm{H})$ treatment. Bars: $60 \mu \mathrm{m}$.

The levels of mPGES-1 immunostaining after gonadotropin treatment are summarized in Tables 2 and 3. A high level of mPGES-1 immunostaining was seen in the granulosa cells of secondary follicles in the untreated group (Fig. 4A). There was no obvious change in mPGES-1 immunostaining at 0.5 and $1 \mathrm{~h}$ after eCG treatment (Fig. 4B, data not shown for $0.5 \mathrm{~h}$ ). After the mice were treated with eCG for $3 \mathrm{~h}$, mPGES-1 immunostaining in the granulosa cells reached the highest level (Fig. 4C). After rabbit IgG was used to replace rabbit anti-mPGES-1 antibody, there was no detectable signal (Fig. 4D). From $6 \mathrm{~h}$ after eCG treatment, mPGES-1 immunostaining gradually dropped to a basal level at $48 \mathrm{~h}$ after eCG treatment (Fig. 4E-H). After the mice were further treated with hCG for $0.5 \mathrm{~h}$, a low level of
mPGES-1 immunostaining was seen in the granulosa cells in the antral and preovulatory follicles (Fig. 4I). mPGES-1 immunostaining was strongly detected in the granulosa cells of preovulatory follicles at $3 \mathrm{~h}$ after hCG treatment (Fig. 4J). From 5 to $11 \mathrm{~h}$ after hCG treatment, mPGES-1 immunostaining gradually dropped to a low level (Fig. 4K and $\mathrm{L}$, data not shown for $5 \mathrm{~h}$ ). In addition, there was no detectable mPGES-1 immunostaining in the oocytes in all of the gonadotropin-treated ovaries.

\section{cPGES expression after gonadotropin treatment}

The levels of cPGES mRNA expression after gonadotropin treatment are summarized in Tables 2 and 3 . There was a low level of cPGES mRNA signal in the granulosa cells 


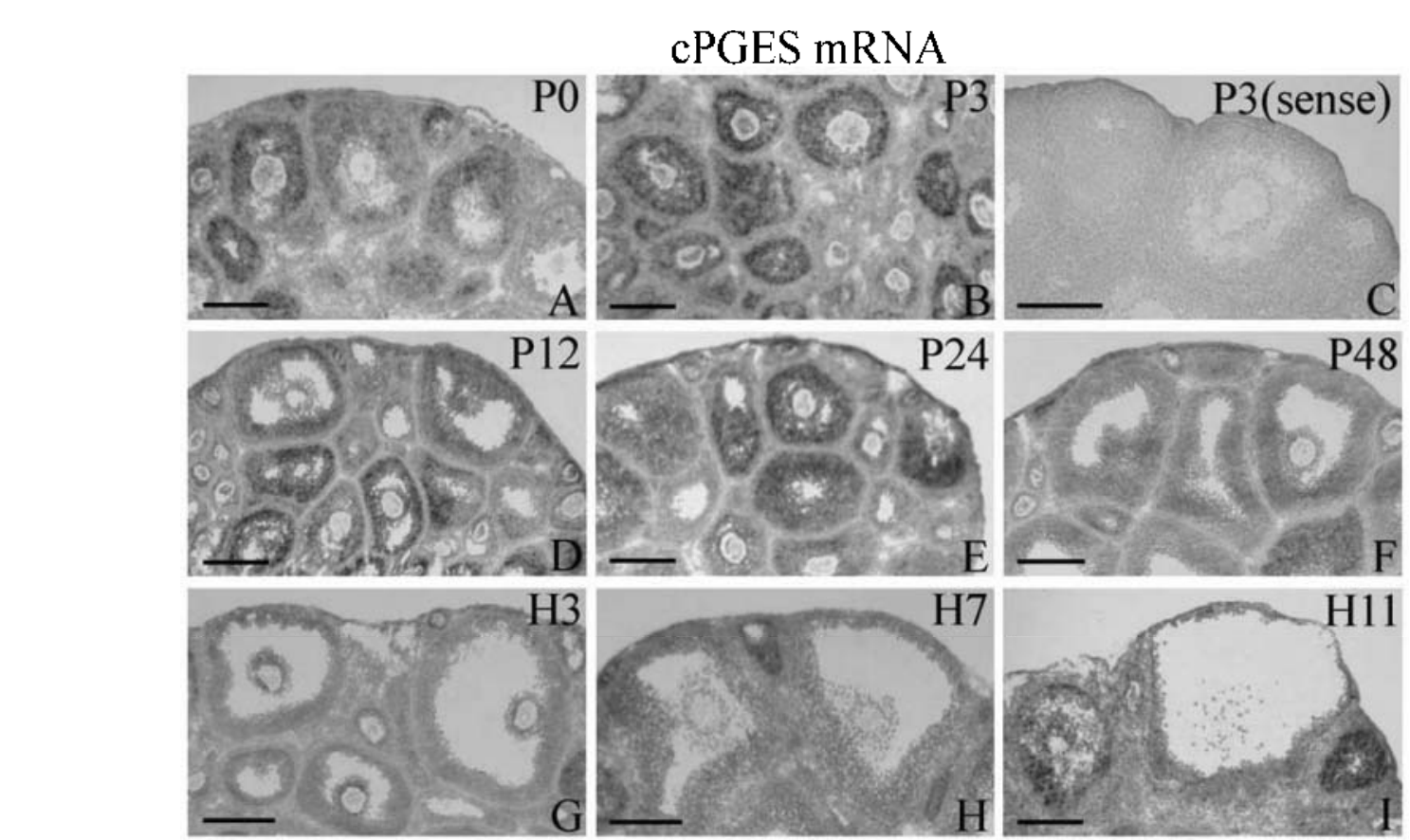

Figure 5 In situ hybridization of CPGES mRNA signals in the immature mouse ovary after the mice were treated with eCG for 3 (B), 3 (C, sense), 12 (D), 24 (E) and $48 \mathrm{~h}(\mathrm{~F})$, followed by the treatment with hCG for $3(\mathrm{G}), 7(\mathrm{H})$ and $11 \mathrm{~h}(\mathrm{I})$. Untreated immature mice were used as controls (A). The letters in the upper right corners indicate the time $(\mathrm{h})$ after eCG $(\mathrm{P})$ or both eCG and hCG $(\mathrm{H})$ treatment. Bars: $70 \mu \mathrm{m}$.

and oocytes in the untreated group (Fig. 5A). cPGES mRNA signals did not change following eCG treatment for $1 \mathrm{~h}$ (data not shown). After treatment with eCG for $3 \mathrm{~h}$, there was a slight increase in cPGES expression (Fig. 5B). When cPGES sense probe was used to replace cPGES antisense probe, there was no detectable signal (Fig. 5C). The level of cPGES expression slightly declined at 6, 12 and $24 \mathrm{~h}$ after eCG treatment (Fig. 5D and E, data not shown for $6 \mathrm{~h}$ ). At $48 \mathrm{~h}$ after eCG treatment, a basal level of cPGES expression was seen in the preovulatory follicles, but a low level was detected in the secondary follicles (Fig. 5F). Further treatment with hCG had no obvious effects on the cPGES expression in the preovulatory follicles, and only a basal level of cPGES mRNA signals was detected in the preovulatory follicles following hCG treatment (Fig. 5G-I).

The levels of cPGES-1 immunostaining after gonadotropin treatment are summarized in Tables 2 and 3. cPGES immunostaining was strongly detected only in the oocytes in the untreated group (Fig. 6A). Treatment with eCG for $1,3,6$ and $12 \mathrm{~h}$ had no significant effects on the level and localization of cPGES immunostaining in the oocytes (Fig. 6B and D, data not shown for 1 and $6 \mathrm{~h}$ ). After rabbit $\operatorname{IgG}$ was used to replace rabbit anti-cPGES antibody, there was no detectable immunostaining in the ovary $3 \mathrm{~h}$ after eCG treatment (Fig. 6C). There was a slight decrease in cPGES immunostaining following eCG treatment for 24, 36 and $48 \mathrm{~h}$ (Fig. 6E and F, data not shown for $36 \mathrm{~h}$ ).
Further treatment with hCG caused a slight increase in cPGES immunostaining (Fig. $6 \mathrm{G}-\mathrm{I}$ ).

mPGES-1 expression during the formation and regression of the corpus luteam

The levels of mPGES-1 mRNA expression in the corpus luteum are summarized in Table 4. There was no detectable mPGES-1 mRNA signal in the newly formed corpus luteum on day 1 (Fig. 7A). However, mPGES-1 signals were strongly observed in the corpus luteum on days 2 and 3 after hCG injection (Fig. 7B and C). From days 5 to 13 following hCG injection, a low level of mPGES-1 mRNA signals was seen in the corpus luteum (Fig. 7D and E). But on day 15 there was only a basal level of mPGES-1 signals in the corpus luteum (Fig. 7F).

The levels of mPGES-1 immunostaining in the corpus luteum are summarized in Table 4. There was a basal level of mPGES-1 immunostaining in the newly formed corpus luteum on day 1 after hCG injection (Fig. 7G). A high level of mPGES-1 immunostaining was seen in the corpus luteum on day 2 (Fig. $7 \mathrm{H}$ ). Then there was a slight decrease in the intensity of mPGES-1 immunostaining on day 3 (Fig. 7I). Only a basal level of mPGES-1 immunostaining was seen on days 7 and 9 (Fig. 7J). From days 11 to 15 , there was a low level of mPGES-1 immunostaining in the corpus luteum (Fig. $7 \mathrm{~K}$ and L). 


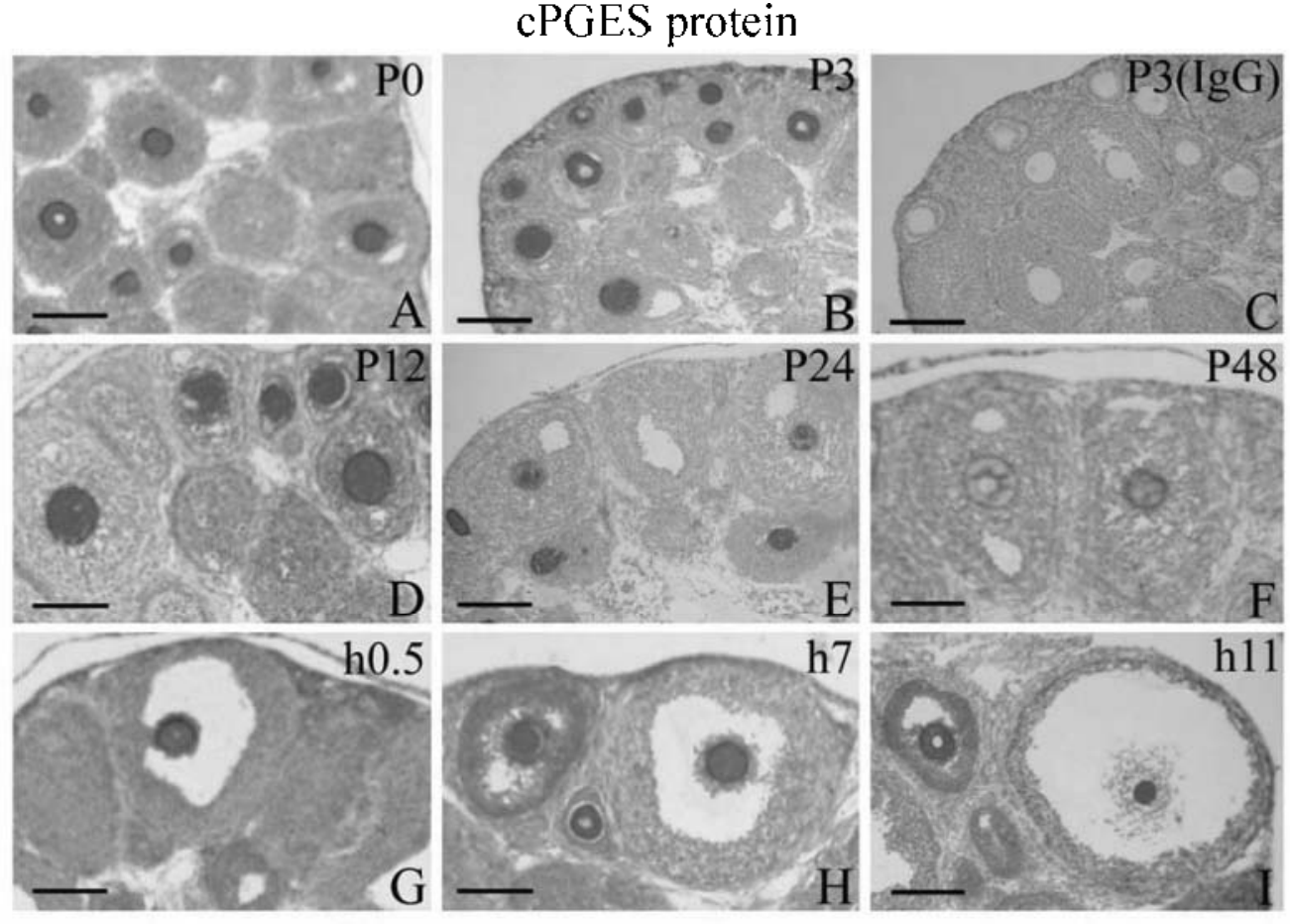

Figure 6 cPGES immunostaining in the immature mouse ovary after the mice were treated with eCG for 3 (B), $3(\mathrm{C}$, rabbit $\operatorname{lgG}), 12(\mathrm{D}), 24(\mathrm{E})$ and $48 \mathrm{~h}(\mathrm{~F})$, followed by hCG treatment for $0.5(\mathrm{G}), 7(\mathrm{H})$ and $11 \mathrm{~h}(\mathrm{I})$.

Untreated immature mice were used as controls (A). The letters in the upper right corners indicate the time (h) after eCG (P) or both eCG and hCG $(\mathrm{H})$ treatment. Bars: $80 \mu \mathrm{m}$.

cPGES expression during the development and regression of the corpus luteum

The levels of cPGES mRNA expression in the corpus luteum are summarized in Table 4. There was a low level of cPGES mRNA signals in the newly formed corpus luteum on day 1 (Fig. 8A). However, a strong level of cPGES mRNA signals was seen on days 2 and 3 (Fig. 8B and $\mathrm{C}$ ). Then the cPGES signals decreased to an intermediate level on days 5, 7, 9 and 11 (Fig. 8D and E). On days 13 and 15 , there was only a basal level in the corpus luteum (Fig. 8F).

The levels of cPGES immunostaining in the corpus luteum are summarized in Table 4 . There was a basal level of cPGES immunostaining in the corpus luteum on days 1 and 2 (Fig. 8G and H). On days 3 and 5, no immunostaining was seen in the corpus luteum (Fig. 8I). On day 7 , a low level of cPGES immunostaining was detected in the corpus luteum. From days 9 to 15, cPGES immunostaining was strongly seen in the corpus luteum (Fig. 8J-L).

\section{Discussion}

Both mPGES-1 mRNA signals and immunostaining were localized in the granulosa cells, but not in thecal cells and oocytes in our study. mPGES-1 expression was also seen

Table 4 Level of mPGES-1 and cPGES in the corpus luteum

\begin{tabular}{|c|c|c|c|c|c|c|c|c|c|c|}
\hline & \multicolumn{10}{|c|}{ Days after hCG injection } \\
\hline & 1 & 2 & 3 & 4 & 5 & 7 & 9 & 11 & 13 & 15 \\
\hline \multicolumn{11}{|l|}{ mPGES-1 } \\
\hline mRNA & - & ++ & ++ & ++ & + & + & + & + & + & $+/-$ \\
\hline Protein & $+/-$ & ++ & + & + & + & $+/-$ & $+/-$ & $+/-$ & + & + \\
\hline \multicolumn{11}{|l|}{ cPGES } \\
\hline mRNA & + & ++ & ++ & ++ & + & + & + & + & $+/-$ & $+/-$ \\
\hline Protein & $+/-$ & $+/-$ & - & - & - & + & ++ & ++ & ++ & ++ \\
\hline
\end{tabular}




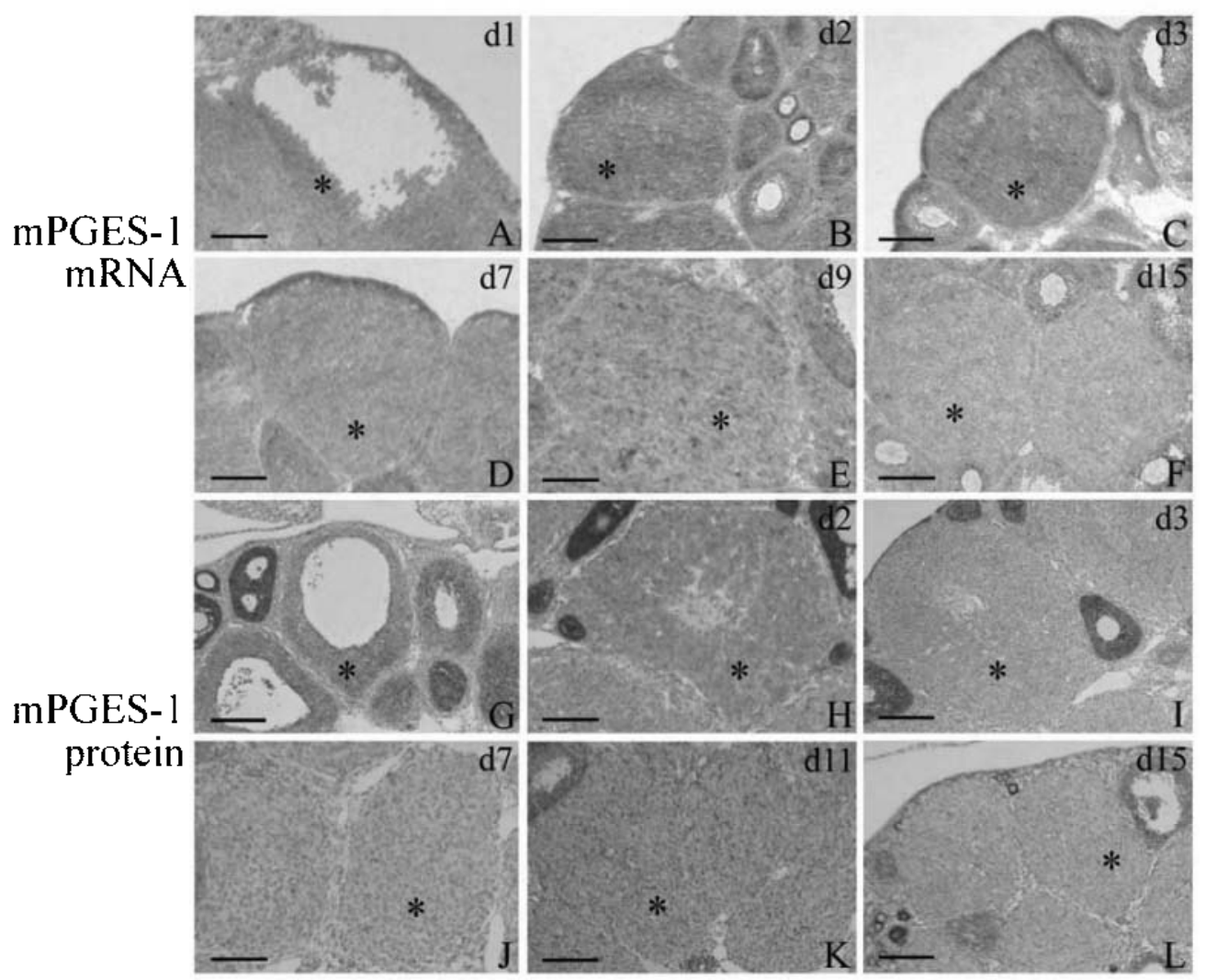

Figure 7 mPGES-1 expression in the mouse ovary during the development of the corpus luteum. In situ hybridization of mPGES-1 mRNA signals was shown in the corpus luteum on days 1 (A), 2 (B), 3 (C), 7 (D), $9(\mathrm{E})$ and 15 (F) post-hCG injection. mPGES-1 immunostaining was shown in the corpus luteum on days $1(\mathrm{G}), 2(\mathrm{H}), 3(\mathrm{I}), 7(\mathrm{~J}), 11(\mathrm{~K})$ and $15(\mathrm{~L})$. The letters in the upper right corners indicate the day after eCG and hCG treatment. *Corpora lutea. Bars: $80 \mu \mathrm{m}$.

in the primary and secondary follicles in mouse and bovine ovaries (Filion et al. 2001, Guan et al. 2001). In the bovine ovary, mPGES-1 protein was detected in extracts of granulosa cells but not in theca interna (Filion et al. 2001). Immunoblot and immunohistochemical analyses revealed that COX-2 protein was selectively induced in bovine granulosa cells. In this study, cPGES mRNA signals were localized in both granulosa cells and oocytes, whereas cPGES immunostaining was exclusively localized in the oocytes. In the female reproductive tissues, cPGES mRNA signals were mainly localized in ovarian primary and secondary follicles in the mouse (Zhang et al. 2003). cPGES is produced as a cytosolic form (Tanioka et al. 2000). Therefore, cPGES expressed in the granulosa cells might be secreted or transported into the oocytes. Moreover, there may be a low level of cPGES protein in the granulosa cells, but the level is lower than the detection limit of our immunohistochemical method. In addition, the signals for EP4 mRNA were localized mostly to oocytes in the preantral follicles (Segi et al. 2003). It is possible that PGE2 produced via cPGES may act through EP4 in the mouse oocytes.

Although the expression patterns of mPGES-1 and cPGES in the mouse ovary during the estrous cycle were not examined in this study, it seems that the expression patterns during follicular development should be very similar between sexual maturation and the estrous cycle. mPGES-1 was strongly expressed in the primary and secondary follicles, but weakly in the antral follicles during sexual maturation and after gonadotropin treatment. Similar expression patterns of cPGES during follicular development were also seen during sexual maturation and after gonadotropin treatment. Nevertheless, follicle-stimulating hormone during the estrous cycle should have a stimulating effect on the expression of both mPGES-1 and cPGES in the follicles because eCG treatment for $3 \mathrm{~h}$ up-regulated both mPGES-1 and cPGES expressions.

In our superovulated model of immature mice, there was a basal level of mPGES-1 mRNA signals in the granulosa cells at $48 \mathrm{~h}$ after eCG treatment. mPGES-1 


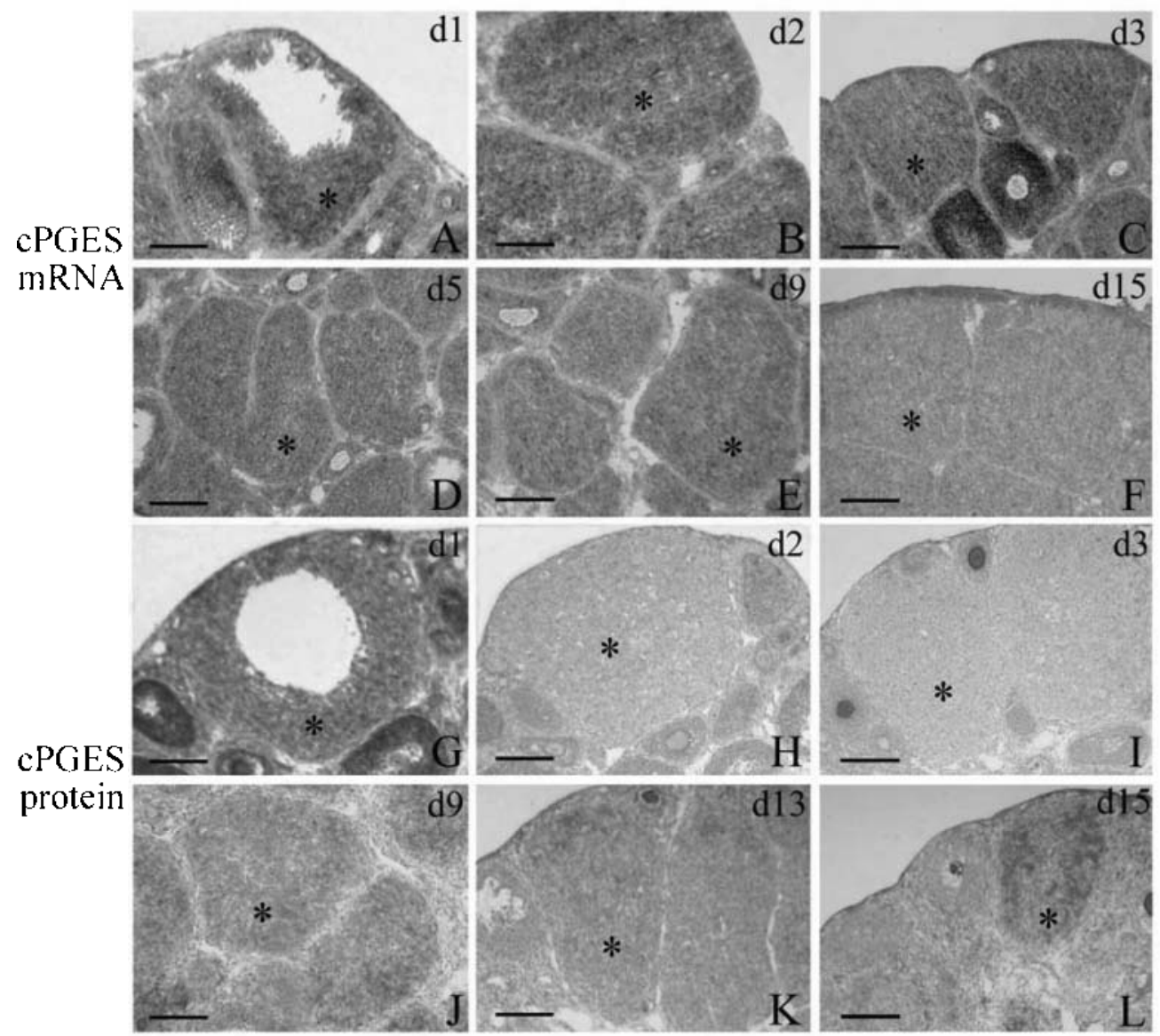

Figure 8 cPGES expression in the mouse ovary during the development of corpus luteum. In situ hybridization of CPGES mRNA signals was shown in the corpus luteum on days 1 (A), 2 (B), 3 (C), 5 (D), 9 (E) and 15 (F) post-hCG injection. cPGES immunostaining was shown in the corpus luteum on days 1 (G), $2(\mathrm{H}), 3(\mathrm{I}), 9(\mathrm{~J}), 13(\mathrm{~K})$ and $15(\mathrm{~L})$ post-hCG injection. The letters in the upper right corners indicate the day after eCG and hCG treatment. ${ }^{*}$ Corpora lutea. Bars: $80 \mu \mathrm{m}$.

mRNA level was induced by hCG treatment for $0.5 \mathrm{~h}$, whereas mPGES-1 immunostaining was slightly induced at $0 \cdot 5 \mathrm{~h}$ after hCG treatment and reached a maximal level at $3 \mathrm{~h}$ after hCG treatment. In the bovine species, the level of mPGES-1 transcripts was low or undetectable prior to hCG/luteinizing hormone (LH), but increased markedly 18-24 h after hCG (Filion et al. 2001). A high level of COX-2 mRNA expression was also found 4 and $12 \mathrm{~h}$ after hCG treatment in the mouse ovary (Joyce et al. 2001). In the immature mouse ovary, both mPGES-1 mRNA signals and immunostaining were significantly induced by $3 \mathrm{~h}$ of treatment with eCG in our study. It appears that mPGES-1 expression in granulosa cells is up-regulated by both hCG and eCG. mPGES-1 is preferentially coupled with the inducible COX-2 to promote delayed PGE2 generation (Murakami et al. 2000). Because COX-2 mRNA expression was present in both granulosa and cumulus cells at $3 \mathrm{~h}$ after hCG treatment (Segi et al. 2003), it is possible that, in the granulosa cells, mPGES-1 should be coupled with COX-2 to produce the PGE2 required for ovulation. Indeed, an $\mathrm{LH}$ surge leads to a high expression of COX-2 in granulosa cells and a stimulation of PGE2 synthesis in the antral follicles (Sirois et al. 1992, 1994). It has been found that LHinduced ovulation was inhibited by non-steroidal antiinflammatory drugs (NSAIDs), and this inhibition could be recovered by the administration of PGE2 (Murdoch et al. 1993). In addition, COX-2(-/ - ) female mice are infertile because of ovulation failure in spite of apparently normal follicular development (Dinchuk et al. 1995, Lim et al. 1997). The ovulation defect in COX-2 mutants was attributed to both an abnormal cumulus oophorum expansion and subsequent stigmata formation (Davis et al. 1999). Cumulus expansion proceeded normally in preovulatory follicles but became abortive in a number of ovulated complexes in $\mathrm{EP} 2(-/-)$ mice, indicating that EP2 is involved in cumulus expansion in the oviduct in vivo (Hizaki et al. 1999). It is possible that PGE2 
produced through the COX-2 and mPGES-1 pathway may act via EP2 for the ovulatory processes.

Both mPGES-1 mRNA signals and immunostaining were highly detected in the corpus luteum 2 days after hCG injection and declined from days 3 to 7 after hCG injection in our study. The level of mPGES-1 mRNA signals and protein slightly increased on day 9 after hCG injection and then gradually dropped to a basal level on day 15 after hCG injection. In the bovine ovary, mPGES-1 immunostaining was localized exclusively in large luteal cells. mPGES-1 staining intensity is at a high level in the growing corpus luteum, and decreases in mature and regressing corpora lutea in the bovine ovary (Arosh et al. 2004). It seems that mPGES-1 may have a role during the growing phase of luteal development. COX-2 expression is associated with the formation of functional corpora lutea via its stimulation of angiogenesis (Sakurai et al. 2003). In addition, EP2 protein is highly expressed in bovine large luteal cells, and the staining intensity for EP2 protein is higher in growing than in mature and regressing corpora lutea (Arosh et al. 2004). Functional EP2 receptors have been detected in human large luteal cells (Harris et al. 2001). It is possible that PGE2 biosynthesized through mPGES-1 and COX-2 may mediate its action via EP2 during the growing stage of luteal development.

cPGES mRNA signals were highly detected on days 2 and 3 after hCG injection, gradually declined from day 5 and reached a basal level on day 15 after hCG injection. cPGES immunostaining was at a basal level or not detectable from days 1 to 7 after hCG injection and was highly expressed in the corpus luteum from days 9 to 15 after hCG injection. cPGES is predominantly linked with COX-1 to promote the immediate PGE2 production (Tanioka et al. 2000). However, COX-1 mRNA and protein are expressed at constant low levels during the entire life span of the corpus luteum (Arosh et al. 2004). PGE2 produced through COX-1 and cPGES should not be essential for luteal function.

In conclusion, the expression profiles of mPGES-1 and cPGES in the mouse ovary during sexual maturation, follicular development and luteal development were first examined in this study. PGE2 biosynthesized through the mPGES-1 pathway may be important for follicular development, ovulation and luteal formation.

\section{Acknowledgements}

This work was supported by Chinese National Natural Science Foundation grants 30270163, 30200196, 30330060 and 30570198, and the Special Funds for Major State Basic Research Project (G1999055903). The authors declare that there is no conflict of interest that would prejudice the impartiality of this scientific work.

\section{References}

Arosh JA, Banu SK, Chapdelaine P, Madore E, Sirois J \& Fortier MA 2004 Prostaglandin biosynthesis, transport, and signaling in corpus luteum: a basis for autoregulation of luteal function. Endocrinology 145 2551-2560.

Challis JRG 1997 Prostaglandins and reproduction - what do knockouts really tell us? Nature Medicine 3 1326-1327.

Coleman RA, Smith WL \& Narumiya S 1994 VIII. International union of pharmacology classification of prostanoid receptors: properties, distribution, and structure of the receptors and their subtypes. Pharmacological Reviews 46 205-229.

Davis BJ, Lennard DE, Lee CA, Tiano HF, Morham SG, Wetsel WC \& Langenbach R 1999 Anovulation in cyclooxygenase-2-deficient mice is restored by prostaglandin $\mathrm{E}_{2}$ and interleukin- $1 \beta$. Endocrinology 140 2685-2695.

Dinchuk JE, Car BD, Focht RJ, Johnston JJ, Jaffee BD, Covington MB, Contel NR, Eng VM, Collins RJ, Czerniak PM et al. 1995 Renal abnormalities and an altered inflammatory response in mice lacking cyclooxygenase II. Nature 378 406-409.

Filion F, Bouchard N, Goff AK, Lussier JG \& Sirois J 2001 Molecular cloning and induction of bovine prostaglandin $\mathrm{E}$ synthase by gonadotropins in ovarian follicles prior to ovulation in vivo. Journal of Biological Chemistry 276 34323-34330.

Guan Y, Zhang Y, Schneider A, Riendeau D, Mancini JA, Davis L, Komhoff M, Breyer RM \& Breyer MD 2001 Urogenital distribution of a mouse membrane-associated prostaglandin $\mathrm{E}(2)$ synthase. American Journal of Physiology: Renal Physiology 281 F1173-E1177.

Harris TE, Squires PE, Michael AE, Bernal AL \& Abayasekara DR 2001 Human granulosa-lutein cells express functional EP1 and EP2 prostaglandin receptors. Biochemical and Biophysical Research Communications 285 1089-1094.

Hizaki H, Segi E, Sugimoto Y, Hirose M, Saji T, Ushikubi F, Matsuoka T, Noda Y, Tanaka T, Yoshida N et al. 1999 Abortive expansion of the cumulus and impaired fertility in mice lacking the prostaglandin E receptor subtype EP(2). PNAS 96 10501-10506.

Jakobsson PJ, Thoren S, Morgenstern R \& Samuelsson B 1999 Identification of human prostaglandin E synthase: a microsomal, gluthathione-dependent, inducible enzyme, constituting a potential novel drug target. PNAS 96 7220-7225.

Joyce IM, Pendola FL, O'Brien M \& Eppig JJ 2001 Regulation of prostaglandin-endoperoxide synthase 2 messenger ribonucleic acid expression in mouse granulosa cells during ovulation. Endocrinology 142 3187-3197.

Lim H, Paria BC, Das SK, Dinchuk JE, Langenbach R, Trzaskos JM \& Dey SK 1997 Multiple female reproductive failures in cyclooxygenase 2-deficient mice. Cell 91 197-208.

Murakami M, Naraba H, Tanioka T, Semmyo N, Nakatani Y, Kojima F, Ikeda T, Fueki M, Ueno A, Oh-ishi S et al. 2000 Regulation of prostaglandin E2 biosynthesis by inducible membrane-associated prostaglandin E2 synthase that acts in concert with cyclooxygenase-2. Journal of Biological Chemistry $27532783-32792$.

Murakami M, Nakatani Y, Tanioka T \& Kudo I 2002 Prostaglandin E synthase. Prostaglandins and Other Lipid Mediators 68-69 383-399.

Murdoch WJ, Hansen TR \& McPherson LA 1993 A review - role of eicosanoids in vertebrate ovulation. Prostaglandins 46 85-115.

Ni H, Sun T, Ding NZ, Ma XH \& Yang ZM 2002 Differential expression of microsomal pge synthase at the implantation sites and in the decidual cells in mouse uterus. Biology of Reproduction 67 351-358.

Ni H, Sun T, Ma XH \& Yang ZM 2003 Expression and regulation of cytosolic prostaglandin E synthase in mouse uterus during the periimplantation period. Biology of Reproduction 68 744-750.

Sakurai T, Tamura K, Okamoto S, Hara T \& Kogo H 2003 Possible role of cyclooxygenase II in the acquisition of ovarian luteal function in rodents. Biology of Reproduction 69 835-842. 
Segi E, Haraguchi K, Sugimoto Y, Tsuji M, Tsunekawa H, Tamba S, Tsuboi K, Tanaka S \& Ichikawa A 2003 Expression of messenger RNA for prostaglandin E receptor subtypes EP4/EP2 and cyclooxygenase isozymes in mouse periovulatory follicles and oviducts during superovulation. Biology of Reproduction 68 804-811.

Sirois J 1994 Induction of prostaglandin endoperoxide synthase- 2 by human chorionic gonadotropin in bovine preovulatory follicles in vivo. Endocrinology 135 841-848.

Sirois J, Simmons DL \& Richards JS 1992 Hormonal regulation of messenger ribonucleic acid encoding a novel isoform of prostaglandin endoperoxide $\mathrm{H}$ synthase in rat preovulatory follicles. Induction in vivo and in vitro. Journal of Biological Chemistry 267 11586-11592.

Smith W 1992 Prostanoid biosynthesis and mechanisms of action. American Journal of Physiology 263 F181-F191.

Sugimoto Y, Narumiya S \& Ichikawa A 2000 Distribution and function of prostanoid receptors: studies from knockout mice. Progress in Lipid Research 39 289-314.

Tanikawa N, Ohmiya Y, Ohkubo H, Hashimoto K, Kangawa K, Kojima M, Ito S \& Watanabe K 2002 Identification and characterization of a novel type of membrane-associated prostaglandin E synthase. Biochemical and Biophysical Research Communications $291884-889$.

Tanioka T, Nakatani Y, Semmyo N, Murakami M \& Kudo I 2000 Molecular identification of cytosolic prostaglandin $E_{2}$ synthase that is functionally coupled with cyclooxygenase- 1 in immediate prostaglandin $\mathrm{E}_{2}$ biosynthesis. Journal of Biological Chemistry 275 32775-32782.

Wallach EE, Wright KH \& Hamada Y 1978 Investigation of mammalian ovulation with an in vitro perfused rabbit ovary preparation. American Journal of Obstetrics and Gynecology 132 728-738.

Zhang Y, Schneider A, Rao R, Lu WJ, Fan X, Davis L, Breyer RM, Breyer MD \& Guan Y 2003 Genomic structure and genitourinary expression of mouse cytosolic prostaglandin $\mathrm{E}(2)$ synthase gene. Biochimica et Biophysica Acta 1634 15-23.

Received in final form 28 November 2005

Accepted 21 December 2005

Made available online as an Accepted Preprint 5 January 2006 